DOI https://doi.org/10.30525/978-9934-26-148-0-14

\title{
ДО ПИТАННЯ ДИФЕРЕНЦАЦІЇ ПОНЯТЬ «ПЕНСІЯ» ТА «ПЕНСІЙНЕ ЗАБЕЗПЕЧЕННЯ»
}

\author{
Галкін В. Л. \\ аспірант кафедри державно-правових дисииплін \\ Луганського державного університету внутрішніх справ \\ імені Е. О. Дідоренка \\ м. Сєвєродонецьк, Луганська область, Україна
}

Питання регулювання пенсійних правовідносин завжди посідало важливе місце в державній політиці. Перш за все це пов'язано з необхідністю реалізації конституційного права на пенсію та впровадження справедливої та економічно обгрунтованої системи призначення пенсій та їх виплат, яка певною мірою є символічним індикатором ефективності правової системи соціального забезпечення. У контексті українського сьогодення диференціація визначень понять пенсії та пенсійного забезпечення має важливе значення з огляду на два чинники: по-перше, це дозволить більш предметно підійти до вивчення проблем пенсійного забезпечення внутрішньо переміщених осіб, кількість яких на сьогодні сягає більше 1 мільйона осіб [1]; по-друге, реформою децентрації, за якої значна частина послуг передається від органів державної влади до органів місцевого самоврядування, що має покращити, а не погіршити якість пенсійного забезпечення [2].

Термін «пенсія» у сучасній доктрині права соціального забезпечення походить від латинського слова «pensio», що буквально означає «платіж». В деяких словниках під пенсією розуміють регулярні грошові виплати як форму матеріального забезпечення непрацездатних [3]. Схоже визначення пенсії знаходимо у Великому енциклопедичному юридичному словнику, проте в ньому надається більш широке тлумачення цього поняття. Зокрема зазначається, що під пенсією слід розуміти грошову виплату, що здійснюється, як правило, один раз на місяць зі спеціально створених фондів особам, які брали участь у системі пенсійного страхування, у разі втрати частково або повністю працездатності для реалізації своїх прав та свобод у повному обсязі [4, с. 614]. Інші джерела надають більш розгорнуте тлумачення функціональної складової цього поняття, визначаючи пенсію як регулярну грошову виплату у якості матеріального забезпечення по старості, інвалідності, за вислугу років, при втраті годувальника [5, с. 380]. 
Водночас виважене визначення поняття пенсії надає Шумило М.М., визначаючи ії як «один із правових інструментів реалізації державою своєї соціальної функції через органи спеціальної компетенції, яка знаходить своє вираження у щомісячному матеріальному (грошовому) забезпеченні» [6, с. 11]. На думку Астрахана Є.І., під пенсією слід розуміти періодичні виплати які здійснюються для матеріального забезпечення громадян у зв'язку зі старістю, інвалідністю, вислугою років чи у зв'язку зі смертю годувальника [7, с. 339]. А ось Ачаркан В.А. доповнив визначення поняття пенсії двома суттєвими ознаками, визначивши, що пенсія за своєю суттю є грошовим утриманням за минулу працю чи іншу суспільно-корисну працю та $є$ постійним основним засобом існування [8, с. 58].

Досить цікаве термінологічне тлумачення пенсії запропоновано правником радянського періоду Гущиним I.В., який визначає пенсію як щомісячні виплати аліментарного характеру, що фінансуються державою та колгоспами. При цьому важливою особливістю пенсії він вважає джерела іiї фінансування (державні та колгоспні кошти), а також безпосередню залежність розміру пенсії від тривалості трудового стажу та розміру колишнього заробітку $[9$, с.40].

Шалієвська Л.І. підкреслює, що пенсія - це «систематична грошова виплата, яку здійснюють відповідні суб'єкти (згідно з законом чи договором), з метою компенсації втраченого (або зменшеного) заробітку та (чи) доходу внаслідок припинення ним трудової діяльності» $[10$, c. 132$]$. Слід також погодитися з цією науковицею стосовно того, що існують певні відмінності між пенсією та іншими виплатами соціального характеру. Зокрема пенсія призначається при настанні ситуацій, які дають на це право, іiї розмір визначається з урахуванням величини i характеру стажу працівника; пенсія встановлюється виключно у грошовій формі як частина раніше відрахованої заробітної плати i виплачується конкретному громадянину; пенсія призначається довічно але періодично переглядається, коли з'являються додаткові відомості про участь пенсіонера у трудовій діяльності. Водночас спірним $\epsilon$ твердження щодо довічності пенсії, адже пенсія може призначатися як довічно, так і на певний строк, наприклад на період встановлення групи інвалідності.

Законодавче визначення пенсії міститься в Законі України «Про загальнообов'язкове державне пенсійне страхування». Зокрема у статті 1 зазначено: «пенсія - щомісячна пенсійна виплата в солідарній системі загальнообов' язкового державного пенсійного страхування, яку отримує застрахована особа в разі досягнення нею передбаченого цим Законом 
пенсійного віку чи визнання іiі особою з інвалідністю, або отримують члени іiі сім'ї у випадках, визначених цим Законом» [11].

В науковій літературі приділена незначна увага поняттю пенсійного забезпечення. Часто дефініція понять пенсії та пенсійного забезпечення ототожнюються дослідниками. До того ж, як зазначалося вище, визначення «пенсії» у деяких словниках пов'язують саме 3 «забезпеченням», а самі поняття пенсії та пенсійного забезпечення безпідставно нерідко уподібнюють, а тому варто дослідити сутність пенсійного забезпечення аби розкрити індивідуальні особливості пенсії та пенсійного забезпечення.

Цікавою є думка Гуцалової Ю., яка визначає пенсійне забезпечення як сукупність інститутів (організацій і правил) та механізмів їх взаємодії, що акумулюють кошти шляхом оподаткування (розподільний) та страхування (накопичувальний) та здійснюють амортизацію наслідків прогнозованих соціальних ризиків згідно встановлених законодавчих правил, які мінімізують наслідки зміни матеріального становища $[12$, c. 90$]$.

Беренцива I.Н. тлумачить поняття пенсійного забезпечення як систему соціально-політичних та економічних відносин у межах проведеної державою соціальної політики, що забезпечує соціальний захист громадян, які не мають можливості продовжувати свою трудову діяльність [13]. А ось Єрошенков С.Г. дає інше визначення - грошова форма матеріального забезпечення для людей, які стають непрацездатними з різних причин. Водночас таке визначення на нашу думку $є$ неповним та не дає чіткого та повного визначення пенсійного забезпечення [14].

Таким чином, наразі відсутнє єдине науково-теоретичне визначення поняття пенсії, однак у більшості існуючих наукових дефініціях мається єдиний об'єднуючий елемент - правовий характер цієї виплати. Незважаючи на джерела фінансування сама теоретична сутність пенсії, визначена науковцями, залишається незмінною - грошова виплата соціального характеру. А от у питанні пенсійного забезпечення основною характерною рисою та загалом метою $є$ безпосереднє отримання грошових коштів - пенсії, адже основне призначення пенсійного забезпечення - виплата грошових коштів та їх отримання пенсіонерами.

\section{Література:}

1. Мінсоцполітики: Обліковано 1459170 внутрішньо переміщених осіб. URL: https://www.kmu.gov.ua/news/minsocpolitiki-oblikovano-1-459170-vnutrishno-peremishchenih-osib 
2. Нестерович В. Ф. Децентралізація як конституційний принцип здійснення публічної влади на регіональному та місцевому рівнях. Науковий вісник Дніпропетровського державного університету внутрішніх справ. 2019. № 3. С. 47-54.

3. Мельничук О.С. Словник іншомовних слів. Київська книжкова фабрика. Київ, 1977. URL: https://ev.vue.gov.ua/wp-content/uploads/2018/ 04/\%D0\%9C\%D0\%B5\%D0\%BB\%D1\%8C\%D0\%BD\%D0\%B8\%D1\%87\% D1\%83\%D0\%BA-\%D0\%9E.-\%D1\%80\%D0\%B5\%D0\%B4.-\%D0\%A1\% D0\%BB\%D0\%BE\%D0\%B2\%D0\%BD\%D0\%B8\%D0\%BA-i $\%$ D0\%BD\%D $1 \% 88 \% \mathrm{D} 0 \% \mathrm{BE} \% \mathrm{D} 0 \% \mathrm{BC} \% \mathrm{D} 0 \% \mathrm{BE} \% \mathrm{D} 0 \% \mathrm{~B} 2 \% \mathrm{D} 0 \% \mathrm{BD} \% \mathrm{D} 0 \% \mathrm{~B} 8 \% \mathrm{D} 1 \% 8$ 5-\%D1\%81\%D0\%BBi\%D0\%B2.pdf

4. Шемчушенко Ю.С. Великий енциклопедичний юридичний словник. Юридична думка. 2007. 992 с.

5. Словарь иностранных слов. Русский язык. 18-е издание. Москва, 1989. $624 \mathrm{c}$.

6. Шумило М. М. Правове регулювання пенсійного забезпечення державних службовців : автореф. дис. ... канд. юрид. наук : 12.00.05. Одеса, 2009. 20 c.

7. Александрова Н.Г. Советское трудовое право: учебник. Юридическая литература. Москва, 1946. 481 с.

8. Ачаркан В.А. Государственные пенсии. Юридическая литература. Москва, 1967. 165 с.

9. Гущин И. В. Советское право социального обеспечения: вопросы теории. Наука и техника. Москва, 1983. 176 с.

10. Шалієвська Л.І. До питання про сутність пенсійного забезпечення населення України. Науковий вісник Львівського державного університету внутрішніх справ. 2018. № 1. С. 130-139.

11.Про загальнообов'язкове державне пенсійне страхування : Закон України від 9 липня 2003 року № 1058-IV. Відомості Верховної Ради України. 2003. №№ 49-51. Ст. 376.

12. Гуцалова Ю. Є. Фінансово-економічна сутність пенсійного забезпечення в Україні. Економічний вісник. 2015. № 2. С. 86-93.

13. Беринцева И. Н. Разработка пенсионной программы в системе социальной направленности деятельности организаций. Социология. Экономика. Политика. 2010. № 1. С. 17-20.

14.Ерошенков С. Г. Анализ закономерностей пенсионного обеспечения за рубежом и определение фактического состояния пенсионной системы России. Юрист. Москва, 2007. 258 с. 